\title{
REVITALIZING HISTORIC AREAS; LESSONS FROM THE RENOVATION OF SAIDPUR VILLAGE, ISLAMABAD
}

\author{
Samra M. Khan*
}

\begin{abstract}
Over the past decades, traditional cities and their historic districts have been deteriorating steadily. The combination of modernity, congestion, old infrastructure and financial pressures have led to migration of people from old neighborhoods and their eventual decline and decay. In league with this loss of traditional cities, in Islamabad, the Central Development Authority (CDA) decided to revitalize the historic village of Saidpur. The project undertook to restore historical architecture, encourage tourism and reverse the cycle of decay by economic and social revival of the area.
\end{abstract}

Saidpur is a small historic village, possibly 500 years old, located at the base of the Margalla Hills. The center of the village has old heritage buildings in the form of two mandirs (temple) and a dharamshala (sanctuary). These were neglected and undergoing rapid deterioration. The infrastructure of the area was underdeveloped, with open drains, unpaved pathways and no solid waste management system.

This paper studies the process and results of this revitalization project analysing the impact of the project on the cultural, social and economic conditions of the village. The methodology of this study was based on qualitative interviews with the residents of the village, CDA officials and direct observation of the spaces (before and after renovation). The paper concludes that the local community must be the engine of any sustainable revitalization of cultural heritage. In the case of Saidpur Village, gentrification without community participation has threatened the social and historic cohesion of the area, leading to brutal transformation and marginalization of local residents.

Keywords: Saidpur, renovation, sustainable revitalization, heritage, community.

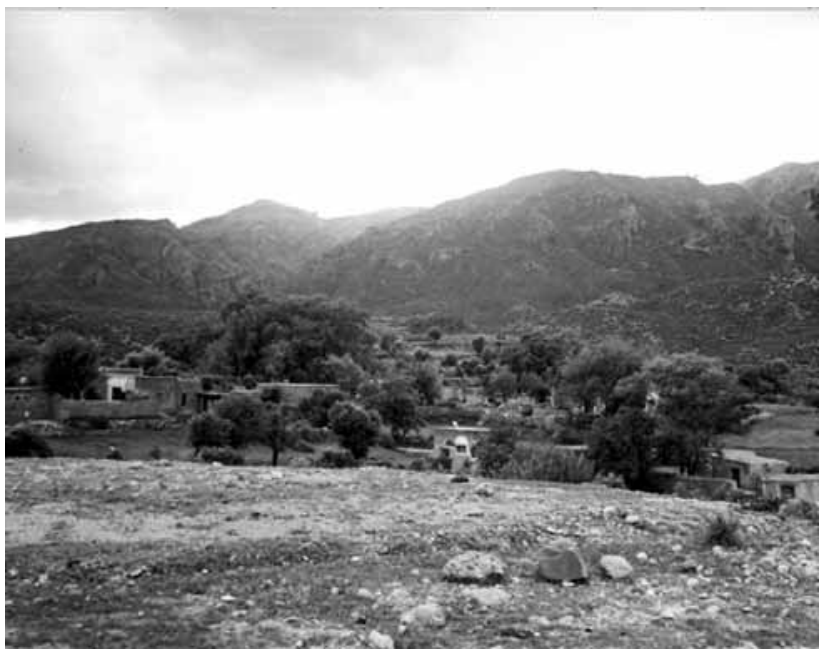

Figure 1: View of villages at the foot of Margalla Hills, Islamabad. Source: CDA Archives

\section{INTRODUCTION}

Before the development of the capital, the area designated for Islamabad consisted of multiple small villages scattered on the foothills of Margalla Hills on the out skirts of the city of Rawalpindi (Figure 1). The CDA acquired these villages including Saidpur Village, Loi Bher Village, Purian village (site of current Shaker Parian), Shah Allah Ditta etc., to build the capital.

After the development of Islamabad, the villages and their historic urban centers underwent transformations in direct consequence of political, socio-economic and developmental policies at national as well as regional level. Saidpur was a small historic village housing religious and cultural buildings in its historic center.

The CDA decided to renovate Saidpur Village in 2005 The need to restore and conserve the historic buildings of Saidpur

* Samra M. Khan is an Associate Professor at the Department of Architecture and Design, COMSATS, Islamabad. 
Village was an important task. In the past, conservation of buildings used to be a passive act; buildings were restored and in cases rebuilt to their original character and thus left as museum pieces to be looked at. To make them environmentally sustainable in the active sense the conservation had to renovate them and find adaptive reuse for them. According to the project architect, one of the premise of the project of revitalisation of the Saidpur Village would have been its contribution to the environment and sustainability of resources and be economically sustainable in the long term.

Renovation of buildings in general, contributes to social sustainability by helping in enhancing the character and image of the community within its boundaries and to the visitors. The interrelation between tourism and historic preservation is well- established, as tourism aids preservation by building awareness and financial support. This paper analyses how the renovation and development of Saidpur Village affected the historic area and what benefits have the residents of the area received from the revitalization. It looks at the steps taken to foster community outreach and economic renewal. The analysis is based on site visits, interviews with residents and CDA officials, newspaper reports and photographic documentation of the development from October 2006 till January, 2011.

\section{HISTORY OF THE VILLAGE AND EXISTING CONDITIONS}

Saidpur Village is a historical place, mentioned in the Punjab Gazetteer of 1893-94. It was inhabited by Muslims, Hindus and Sikhs before 1947. The village has about 16,000 people and around 1,500 households. The village land was acquired by CDA in the late 70 s.

The major historical buildings on site were a Mandir, a Sikh temple and a dharamshala (Figure 2). This temple complex was located on a raised platform surrounded by chequered marble flooring (Figure 3). There were old banyan trees here, an existing old wall and an arched entryway, with steps leading from the complex into the main street. These buildings came under the umbrella of the Auqaf Department and the dharamshala had been converted into a girls' school in order to protect it from demolition. The mandir and the Sikh temple were small structures (measuring $15 \times 15 \mathrm{ft}$ ) and stood on two sides of the complex opposite to each other. The original flooring of the complex had marble tiles commemorating people's donations for the Gurdwara (Place of worship for the Sikhs) complex over many years. This was an important part of the structure's history.

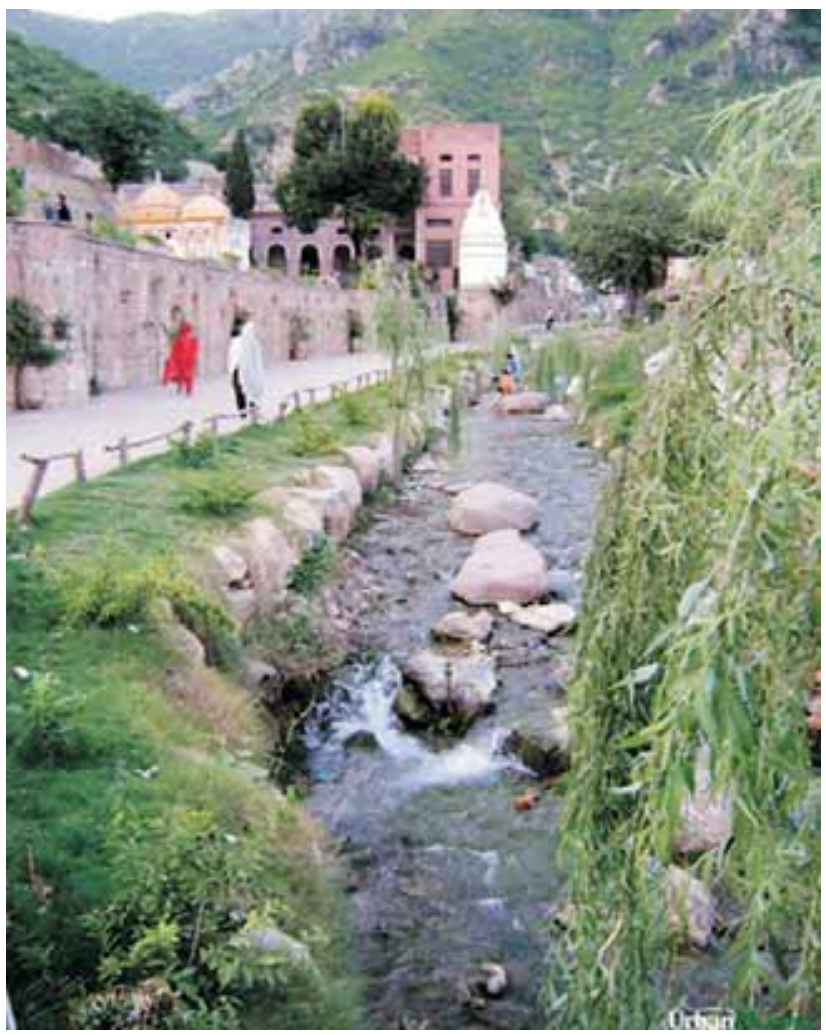

Figure 2: Saidpur Village before renovation Source: www.urbanpk.com accessed 20-3-2010.

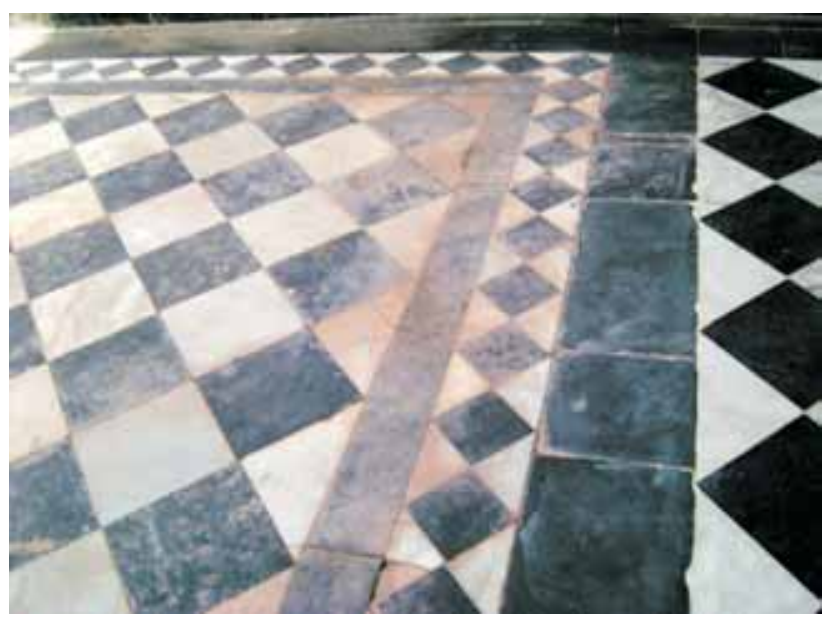

Figure 3: Marble Flooring outside the dharamshala

The old archway connected the temple area with the road running through the village center (Figure 4).

On the surrounding hillside there was an old shrine called the Zinda Pir's Bethak (the seating place of the alive saint) (Figure 5). 


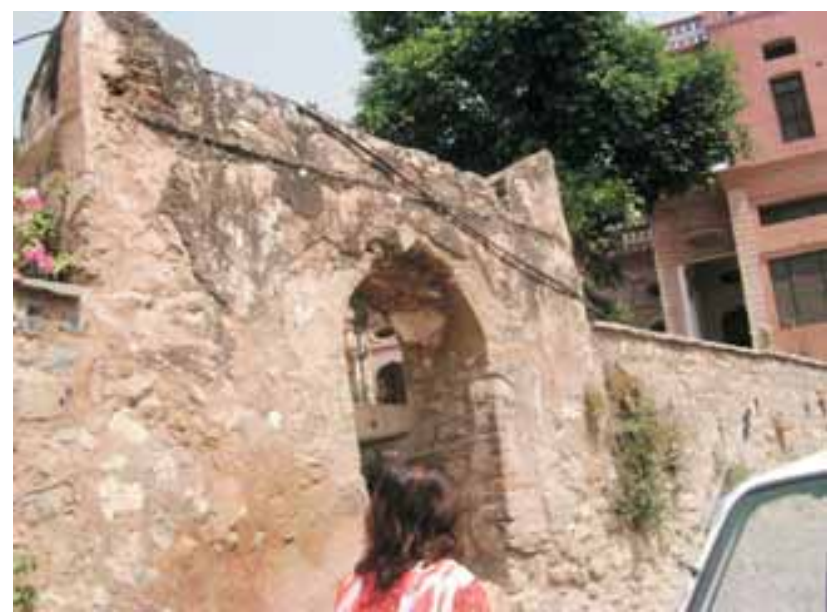

Figure 4: Old Gateway leading to the temple complex

The village has always been famous for its pottery. According to Fauzia Minallah, 'the distinct cultural identity of Saidpur has always been its pottery and it has always been known as the potters' village' (Qalandar, 2008). Over the years many families have moved away to pursue other professions and at the moment there are only two potter families surviving from the original eight.

The village lay on two sides of the central nalla ( storm water channel) and lacked sanitation and drainage system. Due to this all refuse water and sewage was directed into the central nalla. There was no solid garbage disposal system in place.

\section{CASE STUDY: RENOVATION OF SAIDPUR VILLAGE, ISLAMABAD}

The CDA undertook the development of Saidpur into a 'model tourist village'. Around 400 million Pak Rupees were spent on the project. The renovation aimed to preserve Saidpur as a cultural heritage site for tourists and a tourist spot for local residents of Islamabad. The renovation started in 2006 (Figure 6) and work was carried out on the main historic structures until 2008. A number of interventions took place to improve the physical environment and to restore/ renovate the historical buildings and to improve cultural and economic conditions of the village. Saidpur Village was developed as a model village to attract tourists on the lines of folk villages in European countries (Khan and Imdad, 2010).

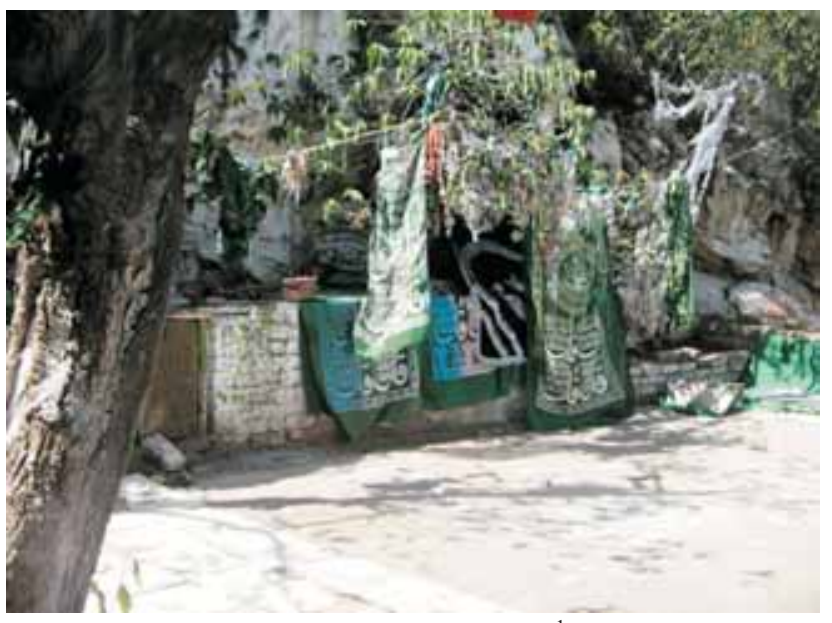

Figure 5: Baithak of Zinda Pir in Saidpur village ${ }^{1}$

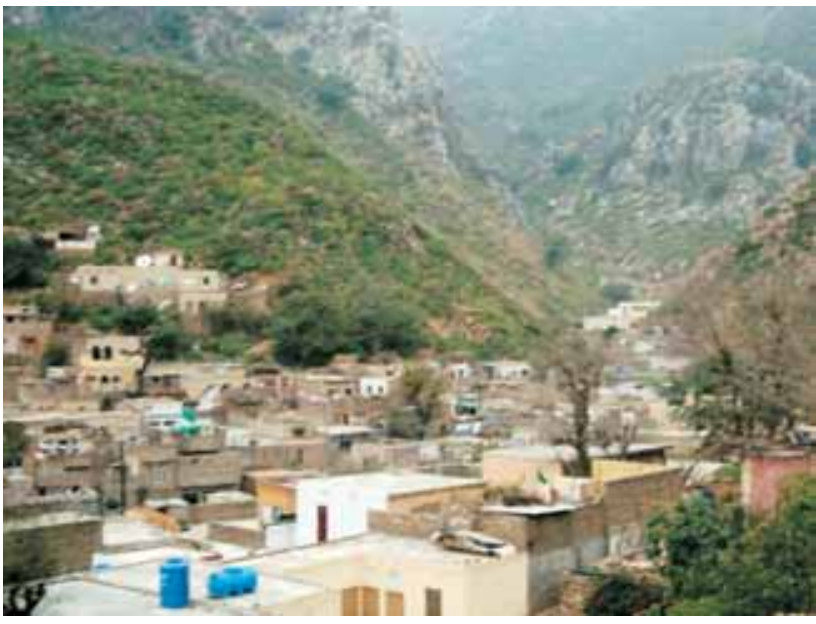

Figure 6: Saidpur at the start of the renovation (2006)

The masterplan included the plan to develop a major arts and crafts village nearby, with an intention to house the artisans, their shops and display booths. The village center would planned to be developed to house a combination of restaurants, cafes, a museum, an art gallery and handicraft and souvenir shops showcasing local goods (Figure 7).

The CDA promised the residents that the whole village would benefit from the renovation: water supply, gas supply and drainage pipes would be put in the whole area. A garbage removal system would be provided. According to a local resident the restaurants and shops would employ the locals and contribute to the economic development of the village.

1 Reproduced by permission; Taken by Aisha Imdad 


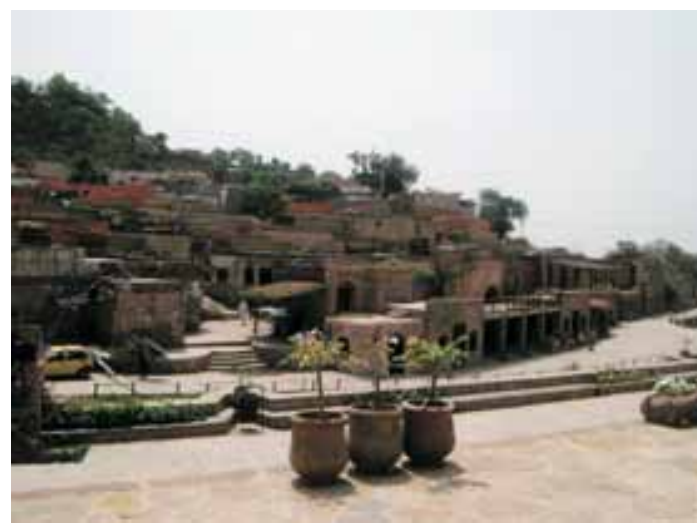

Figure 7: Initial renovation of village in 2006

The CDA also undertook many controversial steps as it acquired land by removing villagers' homes as encroachments from key areas of the village center; it promised compensations and relocation, according to a local architect.

Mr. Kamran Lashari (Chairman CDA) in November 2008, set up a task force that conducted a survey of the village and adjoining Margalla Hills (Admin, 2009). The task force was to take appropriate steps to find about illegal construction in the area and to demolish all the houses built for commercial purpose as these activities were creating civic problems which were ruining the beauty of the village. The scope of work included the demolition of many buildings, development of a dam and other water retaining structures, concrete repairs, landscaping and horticulture design interventions, fixing of the water supply, sewage works, piling, development of bridge structures, restoration and conservation of buildings, development of road infrastructure, electric works, water proofing and other civil works. The CDA authorities are still struggling to find solutions to the issues of encroachments, acquisition of land and compensation for the villagers (The Nation, 2008).

\section{Restoration of Major Historic Buildings}

The C.D.A. has devoted its maximum effort on working on the existing historic structures at the site; the old mandir and dharamshala (Figure 8). The dharamshala renovation was carried out in a sensitive manner by retaining its character by using near to original materials, colors and textures. The original marble floor of the dharamshala, dating from the early 1900 s was in fairly good condition, this was cleaned and retained.

The dharamshala was converted into a museum for the city of Islamabad (Figure 9). The re-adaptive use of the

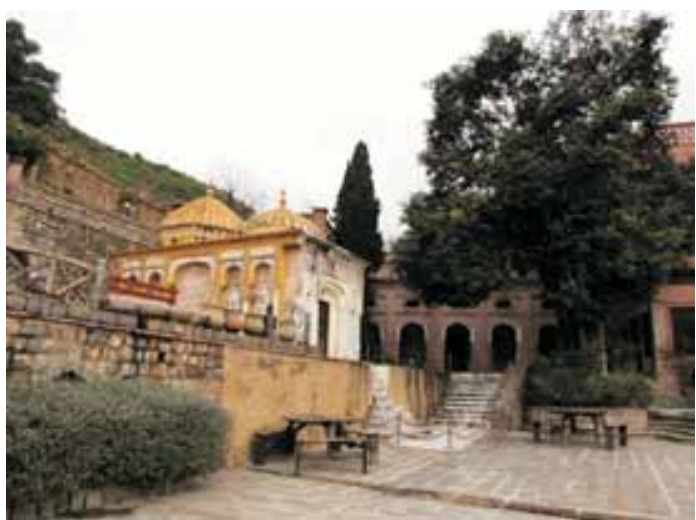

Figure 8: The complex of Temple Mandir and dharamshala

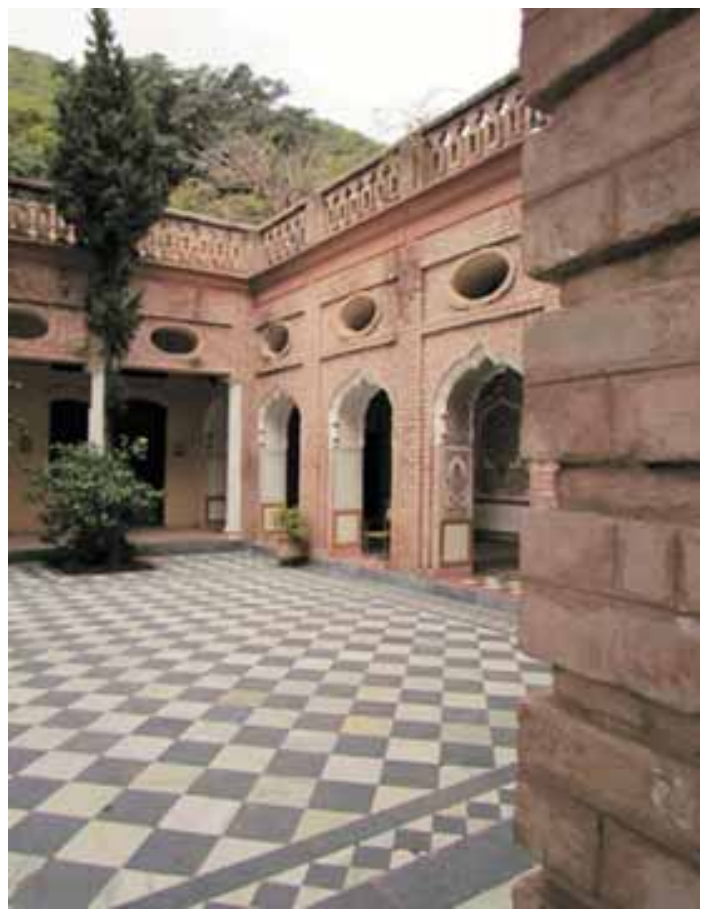

Figure 9: View of the renovated museum and marble flooring

dharamshala/ school into a museum/ gallery space was a very positive step in the renovation of the building. The original brick façade of the dharamshala was retained and this added to the character of the buildings. However, the internal walls of the veranda were covered with brightly painted floral patterns. The patterns and colors were more reminiscent of truck art and had no connection with the original buildings. This was contrary to the standards for historic restoration, that states that designs that are never executed historically should not be constructed (Figure 10). 


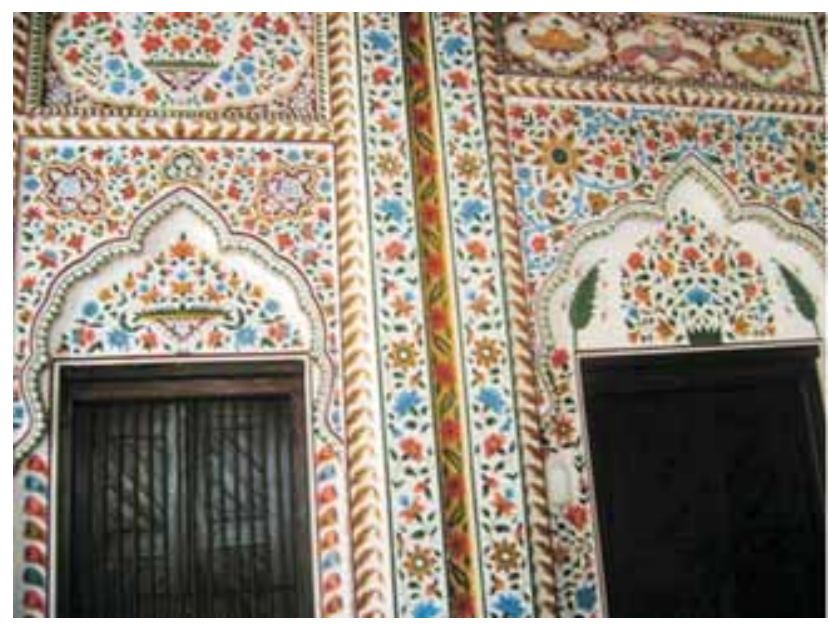

Figure 10: Repainted walls of the dharamshala

The restoration fell short on these aspects and no studies or documentation of existing buildings were carried out to determine the existing decorative elements. All the buildings were white washed losing all of the original existing details of the mandir and temple. The over-painting of garish and inauthentic motifs gave the whole renovation an artificial look. The patterns of birds and the Jahangiri inspired fruit bowls were details not indigenous to the area. These details reduced the integrity of the renovation (Figure 11).

The Athens Charter for Restoration of Historic Monuments (ICOMOS, 1931) states, 'proposed restoration projects are to be subjected to knowledgeable criticism to prevent mistakes which will cause loss of character and historical values to the structures.' In the case of Saidpur Village, studies on the history and architecture of the village were not carried out and experts in conservation/ restoration were not involved.

\section{New Construction around Temple Complex}

Renovation of the area of the temple complex included building new structures next to it. These structures were built in stone and had a different character to the traditional brick structures of the village.

New buildings were allocated to restaurants (Des Pardes) with outdoor seating that spills into the temple courtyard (Figures 12, 13). Two chattri (umbrella) structures were erected at the entrance. The design and size of the two structures seemed out of place within the historic complex. Aesthetically they fail to add anything to the space (Figure 14).

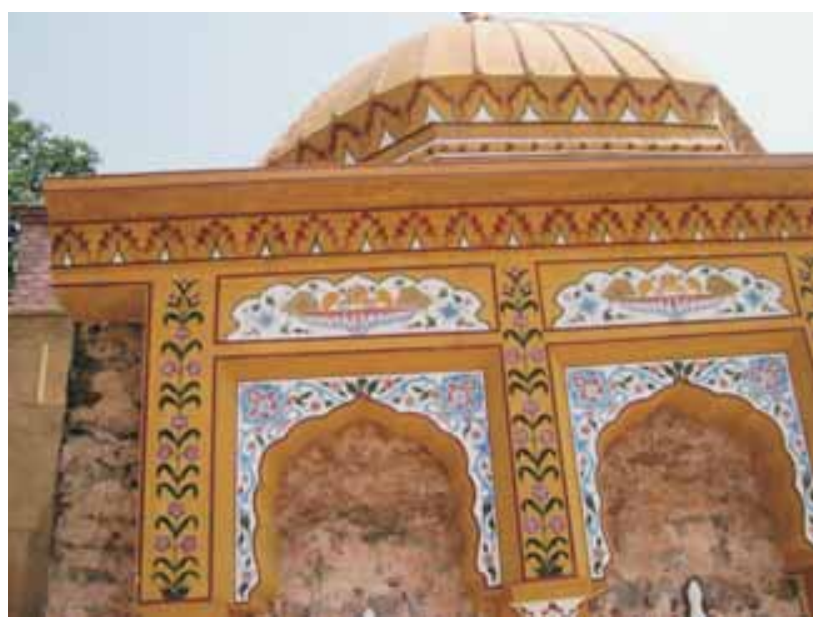

Figure 11: Repainted façade of the temple

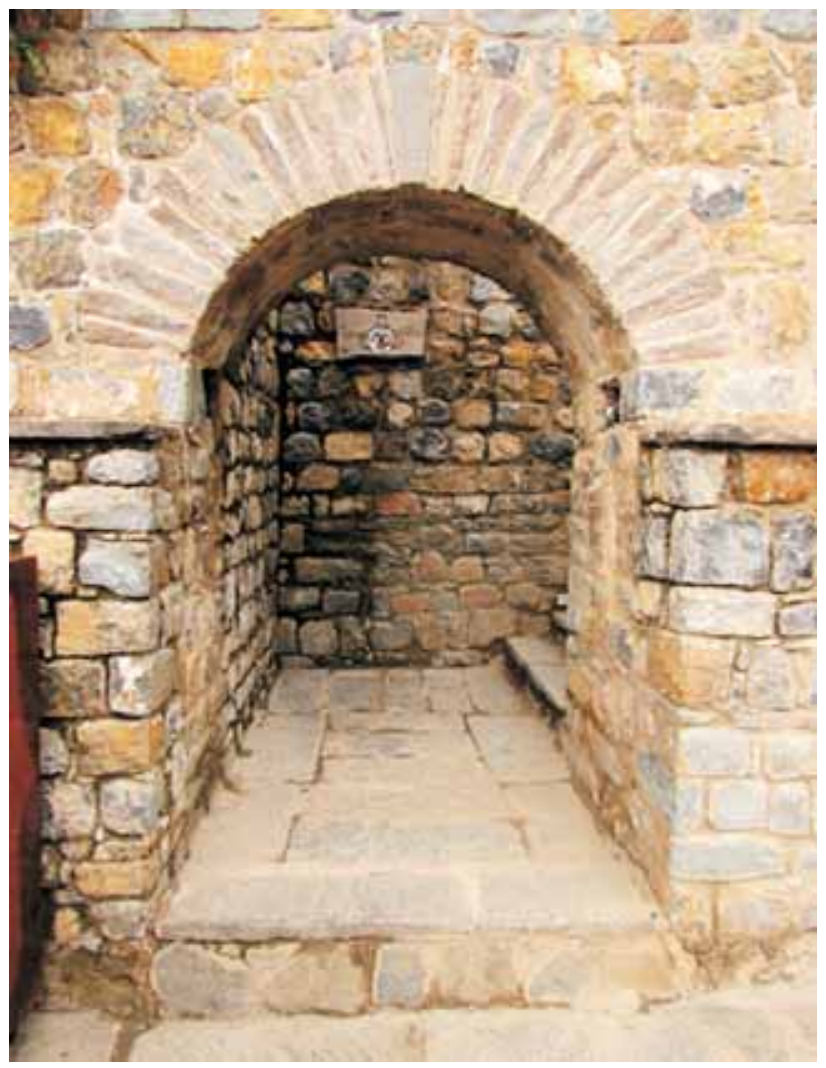

Figure 12: Doorway and steps leading to hotspot on hillside 


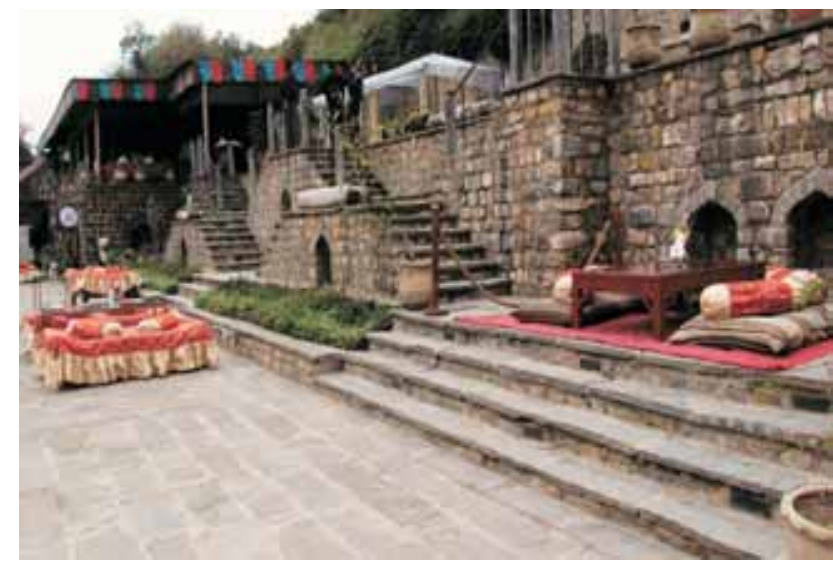

Figure 13: Seating area of restaurant

\section{Renovation of the Village and Improvement Work}

The work done by C.D.A. included the cleaning up of the entrance to Saidpur Village from the main road. This area was decorated with haystacks and new palm trees were planted all along the winding road which lead to the main entrance.

An adobe gate was erected at the entrance to the village; it was built in Pueblo Style. The design and color was unrelated to the surrounding landscape and to the character of the village (Figure 15).

A lot of effort was made in improving the approach to the village by cleaning up the old buildings along the road. The houses on both sides of the entrance were vacated and their facades were rebuilt in stone to give a traditional look. The street now appears neater and cleaner but does not reflect the layout of a traditional street. These new premises were converted into expensive shops and cafes (Figures 16, 17).

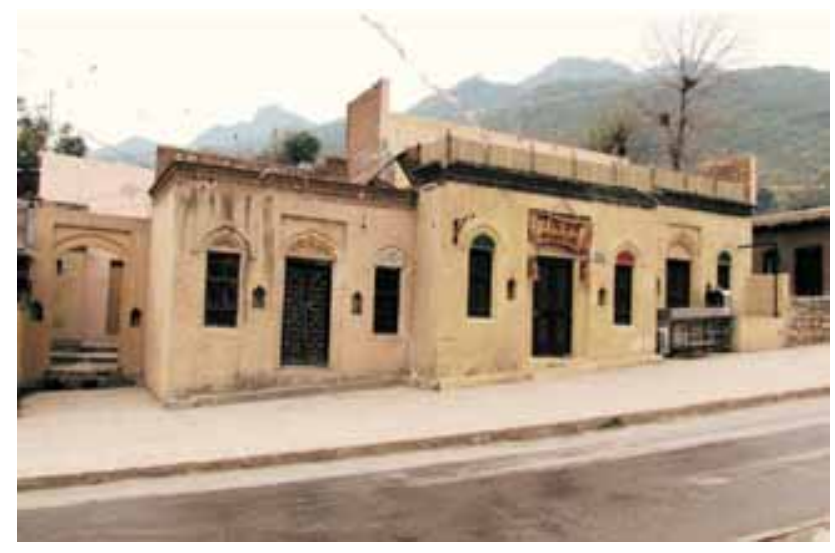

Figure 16: Reconstructed facades of shops

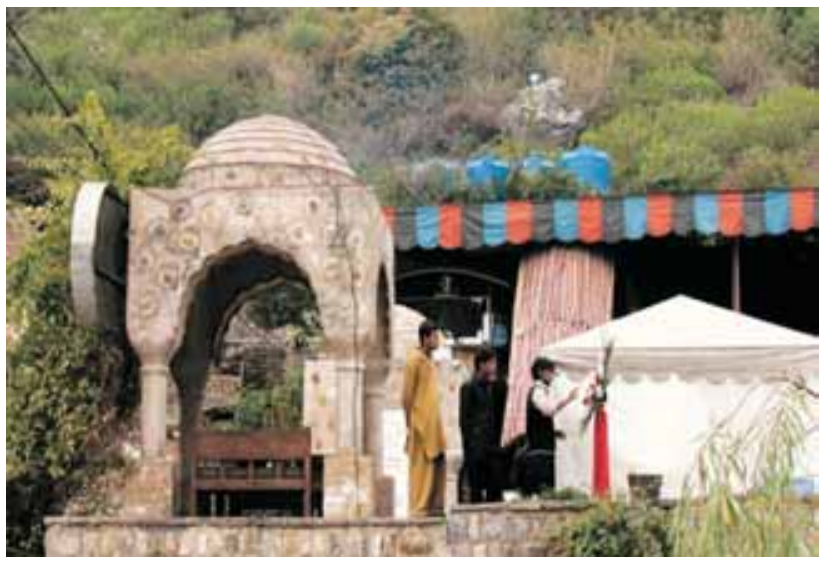

Figure 14: Chattri structure at the entrance of temple complex

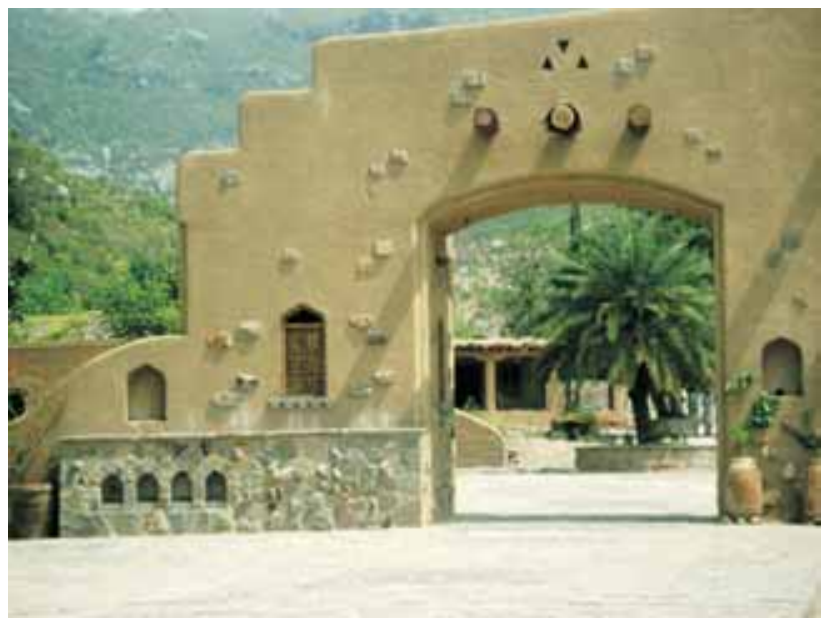

Figure 15: New entrance gate of the village

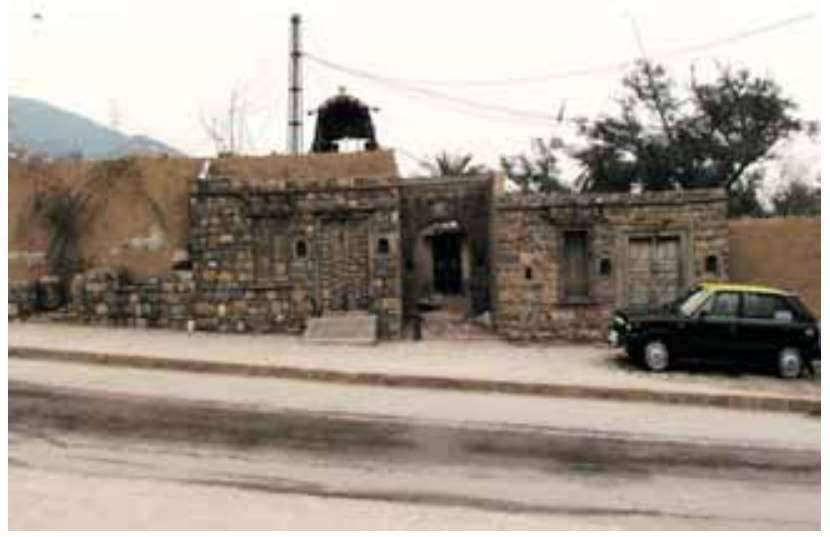

Figure 17: Reconstruction work 


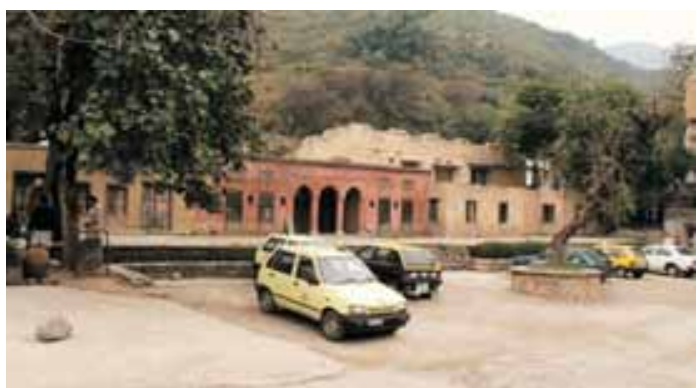

Figure 18: Parking outside village

The main road leading to the village opened up into a large parking area. This vast parking space can accommodate almost 500 vehicles (Figure 18).

The parking has also been bought into the central part of the village which used to be a pedestrian area (Figure 19). The new businesses have exerted pressure on the authorities and as a result cars are parked next to the restaurants. A better plan would have been to keep the center of the Village as a pedestrian area, this would have added to the historic fabric and ambience of Saidpur. Instead the area now offers a commercial look with multiple restaurants and cars.

The central nalla of the Village was envisaged to be the hub of all activities and two major restaurants and some souvenir shops were placed on both sides to increase tourism. The village nalla was also uplifted by paving its sides. The façades of the houses next to this area were also uplifted by plastering them with mud and painting them in 'indigenous colours' (Figure 20).

Traditionally, the potters of the village had worked and displayed their work in their houses. People used to visit their homes to buy their wares (Figures 21, 22). In 2007, the potters of the village were given new shops in the center of the village to display their talents and works. This was a positive step towards showcasing the indigenous talents of the crafts persons.

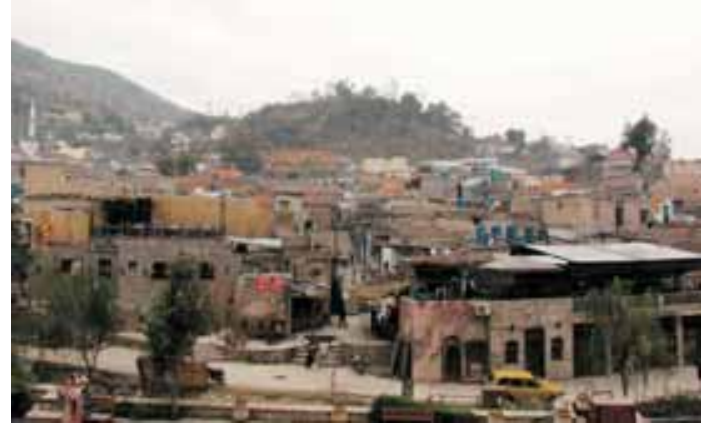

Figure 20: Façades of houses painted in orange

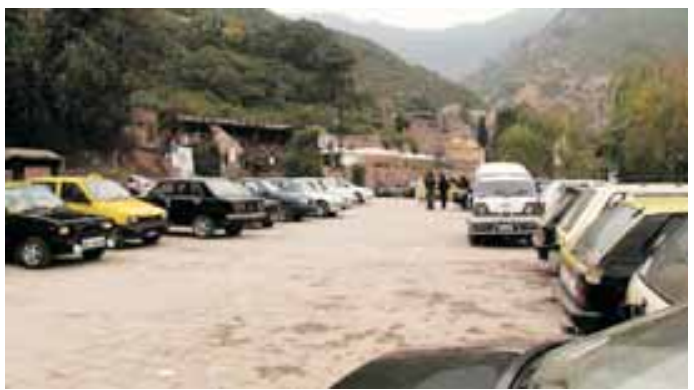

Figure 19: Parking areas inside the village

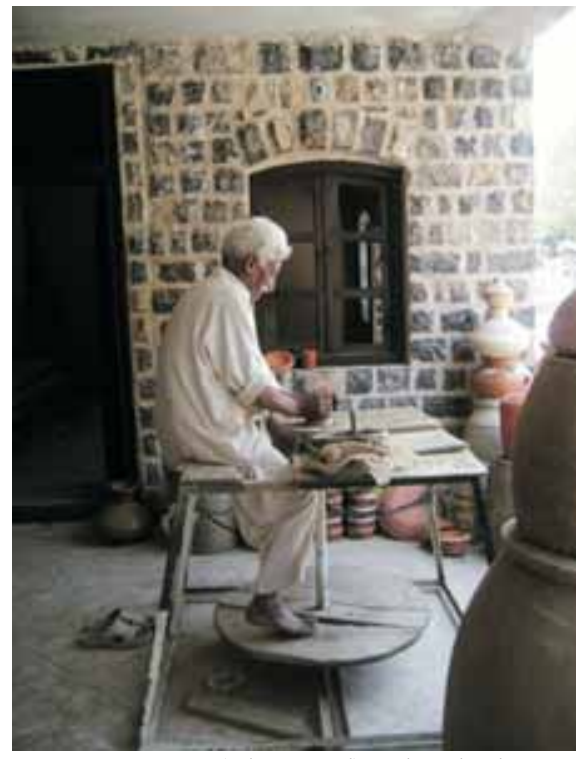

Figure 21: Potter (Aleem Dad) at the wheel

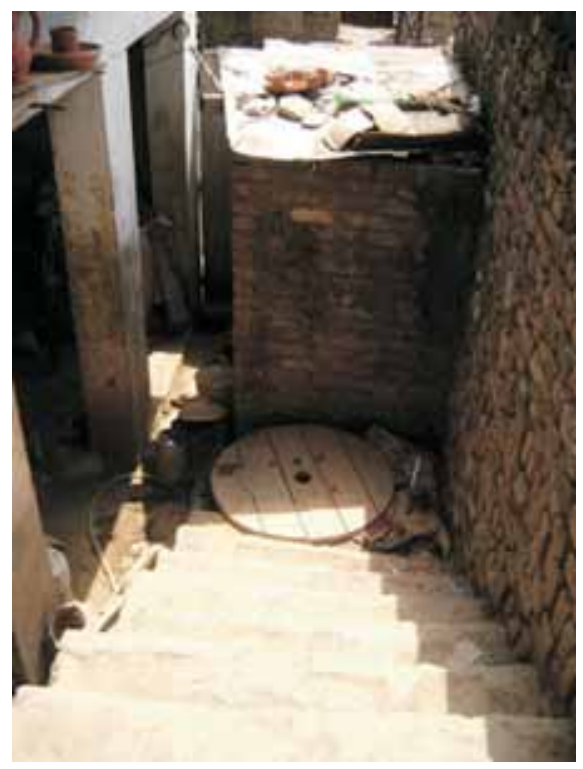

Figure 22: Entrance of potter house 


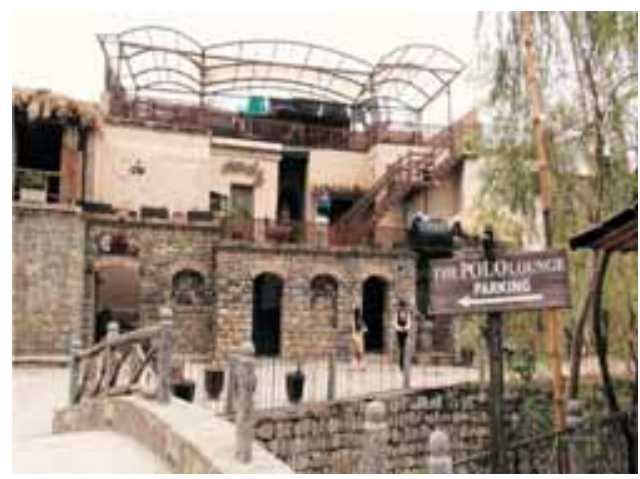

Figure 23: Polo lounge occupies the area where the potter's shops were located

With time however, the potters and their shops were pushed out of the area and posh restaurants dot the front of the Village (Figure 23).

The central area of the Village was also paved and the nearby main street was paved with stone and concrete. The open drains were covered and the façades were cleaned up. Many façades were redone to reflect "history" with various style arched openings and doors (Figures 24, 25).

But further away from the tourist center the streets remain broken and filthy (Figure 26). The storm water nalla was also paved and maintained near the center of the village (Figure 27) but towards the rear of the village it was full of garbage and sewage (Figures 28, 29). Due to lack of a proper garbage disposal system the nalla became a dumping place for refuse. The open sewers and drains from the houses flow into the central nalla.

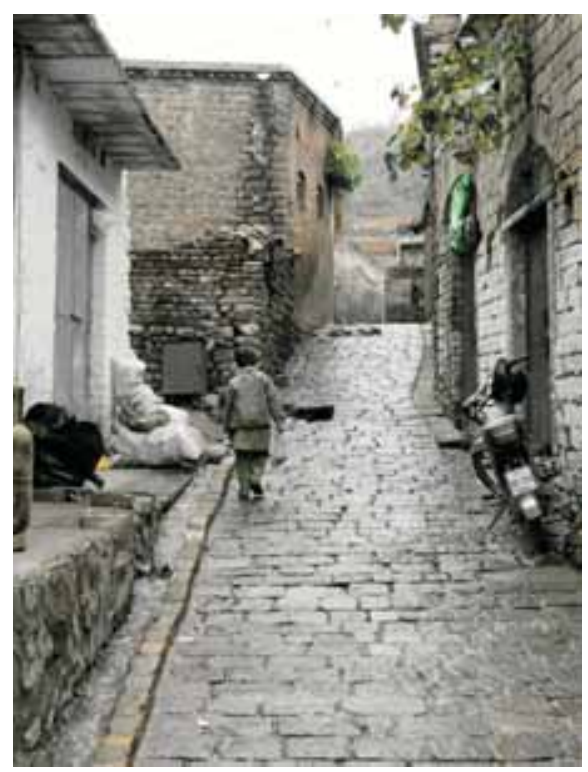

Figure 25: Stone paved street

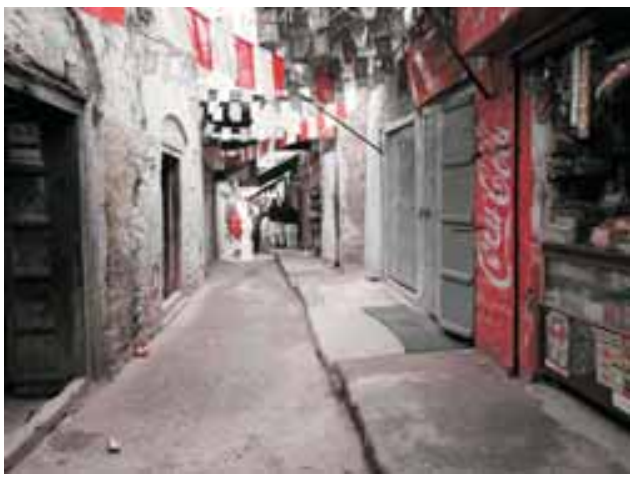

Figure 24: Paved street and reconstructed facade

The C.D.A. has not completed the project to remove dirty water and sewer waste away from the nalla. The open sewers and their waste water in the nalla added to the smell and visual pollution of the village.

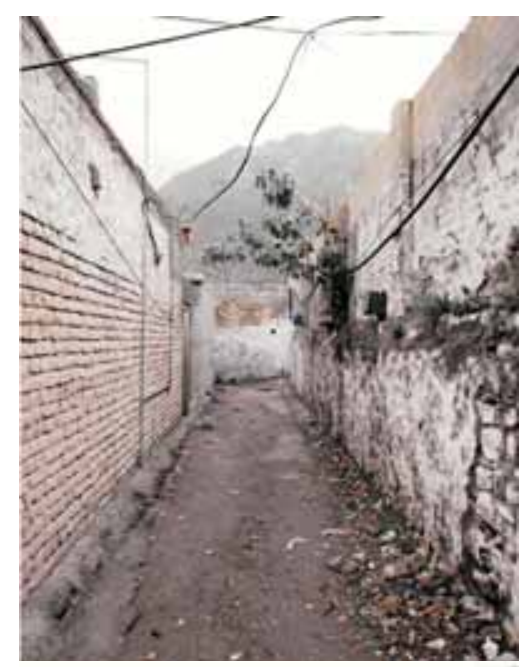

Figure 26: Unpaved street

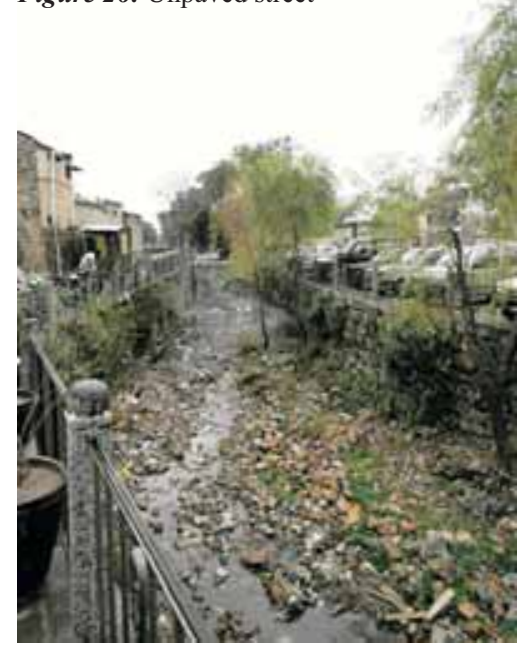

Figure 27: Nalla paved in central area 


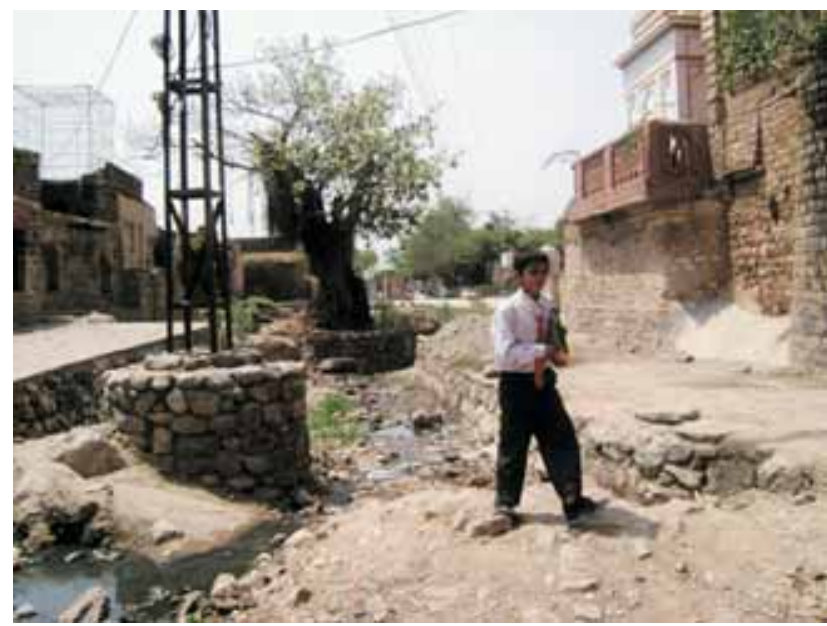

Figure-28: Garbage littered nalla in village

\section{Analysis of Renovation works undertaken at Saidpur Village}

Analysing the overall strategies for the management of cultural heritage resources of Saidpur Village by CDA it is revealed that a sustainable development framework was not developed or followed for the project. The restoration of the historic structures was done in a superficial manner. The dharamshala building was only painted and plastered on the front but the back was left untended (Figure 30). The project did not bring in any qualified conservation experts for restoration. Neither were the motifs or design existing in old houses and structures reflected in any of the new construction. Many old buildings, which were clearly historic assets, were left in disrepair and pushed to the background of the development.

These historical buildings and the many old trees on the site defined the cultural, social and historic roots and origins of the Village. Most of the new construction camouflaged the historic fabric or completely removed it (Figures 31-33). The development gave new construction more importance as compared to the existing structures which defined the character of the village.

A sustainable development approach would have allowed all these original aspects to be taken into account $t$ before introduction of tourism into the fabric of the village.

Due to lack of garbage disposal and adequate waste collection facilities, the environmental improvements envisaged for the site were not realized. The quality of life for the ordinary resident of the village did not improved. Streets and stairways

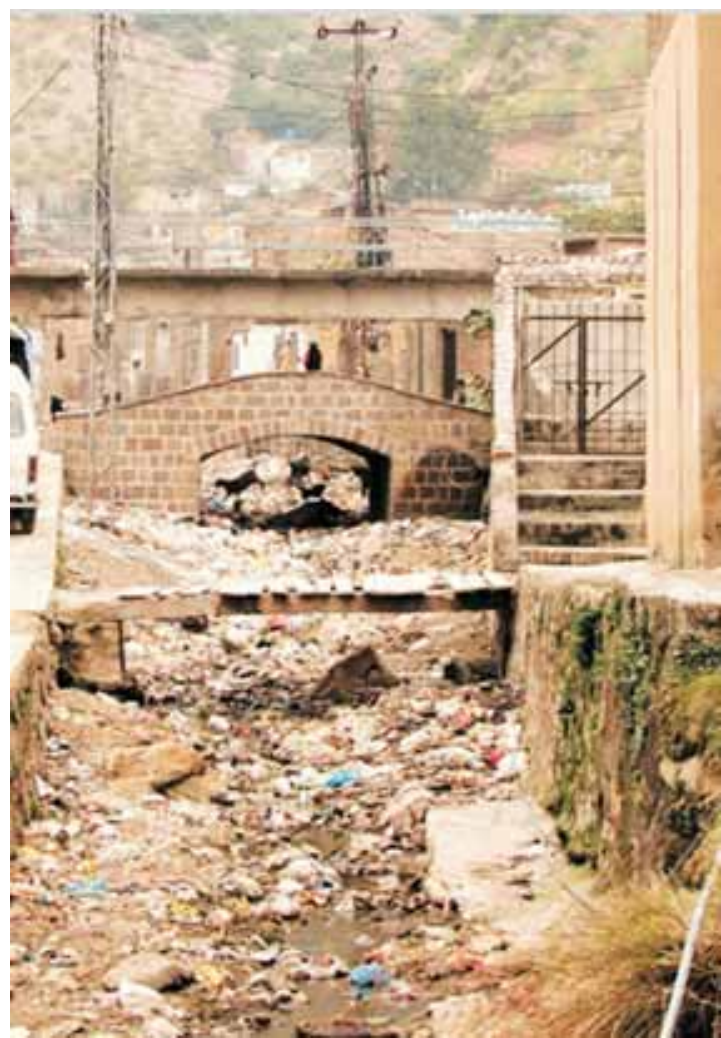

Figure-29: The nalla is filled with garbage between houses

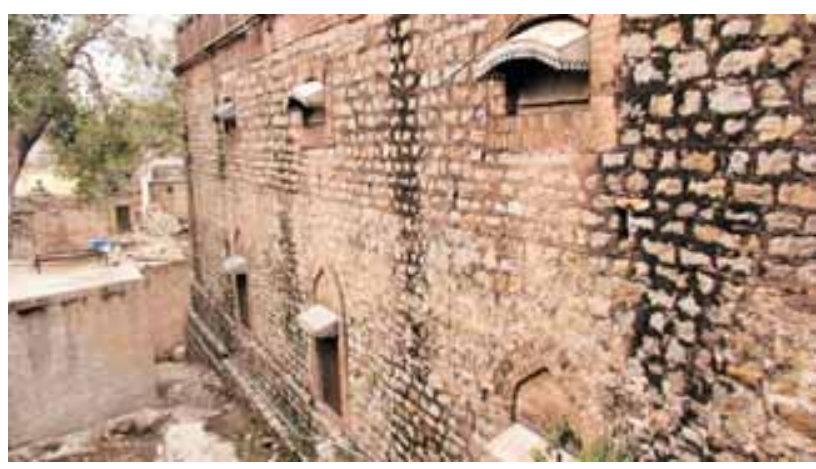

Figure-30: The back facade of the dharamshala

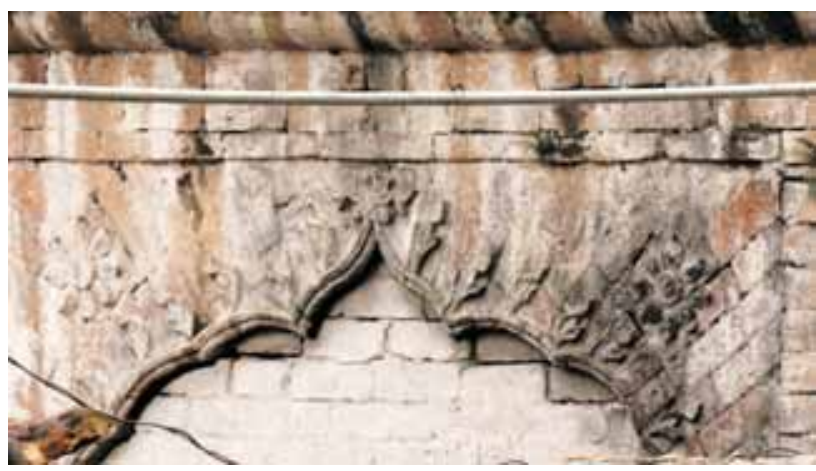

Figure-31: Decorative brick work on a doorway 


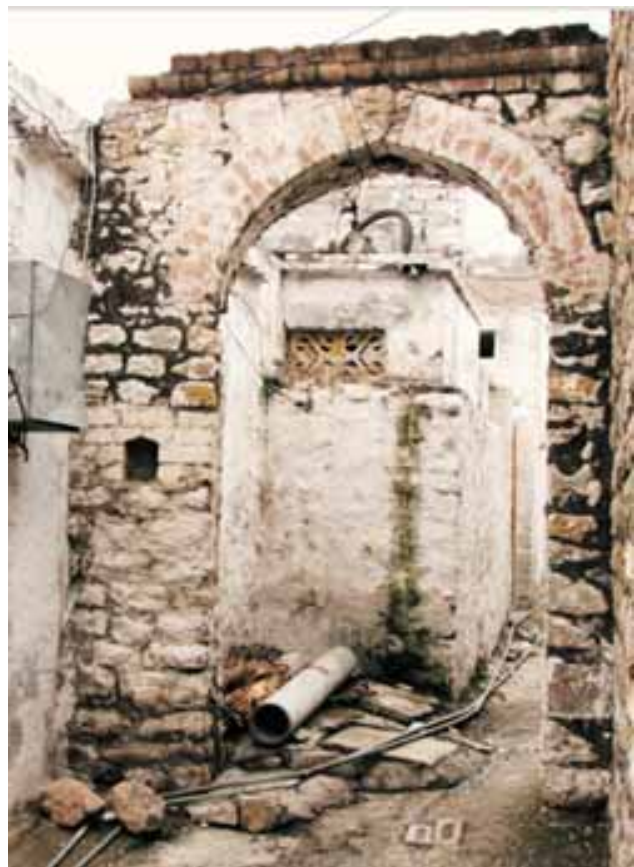

Figure-32: Historic doorway in village

throughout the village remained unpaved and broken. The sewage lines were non-existent. The waste water and sewage flew through the streets unattended.

The economy of the village did benefit initially from this project because of the employment of local people into the building trade and use of crafts persons. The local shopkeepers also found some business catering to the increased construction activity in the village. But in the long run the restaurants on the main street of the village started being owned and managed by outsiders and employees were from outside the village too. Thus, the economic benefits were not transferred to the inhabitants of the village. With time the development of the central area of the village gave in to consumerism and commercialization. The restaurants and parking areas remained designated for the elite which facilitated the visitors rather than the local residents.

There were no steps taken to encourage social rehabilitation of the residents and to introduce any social diversity, such as coexistence of the multiple functions of residential and tourist areas. In spite of CDAs pledges to the community in order to ensure their compliance, no sustainable development took place in line with the Rio Declaration Principles of Sustainable Development (UNEP, 1992) related to community participation which states that communities are

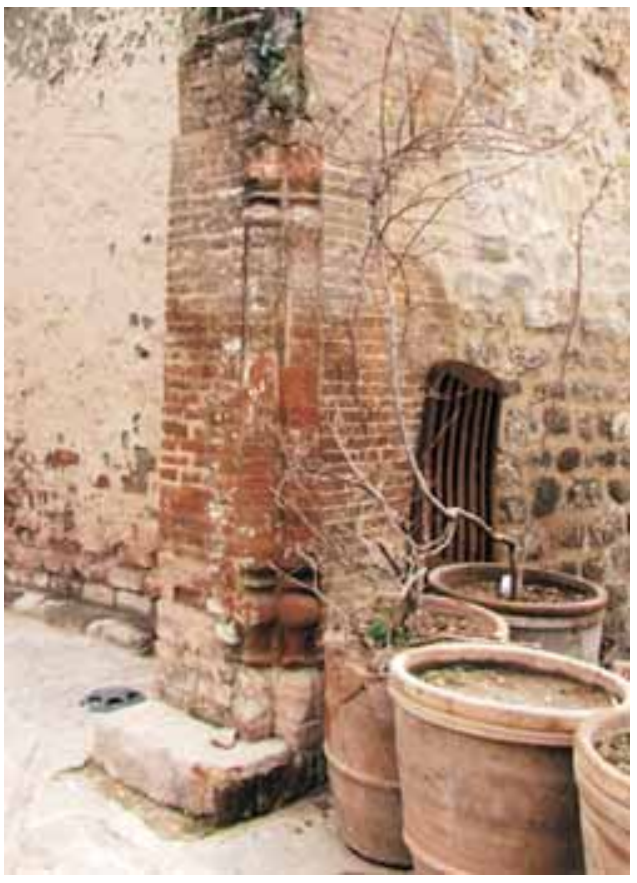

Figure-33: Remnant of old decorative brick columns

carriers and immediate custodians of cultural resources (UNEP, 1992).

In the case of Saidpur Village, the local community was marginalised in both the social and physical contexts. All over the world sustainable and successful practices in restoration engage the local population and encourages them to be stakeholders in projects as the success of the restoration depends on the active participation and direct financial involvement of the local population (Jing, 2008: 69).

Conclusively, the Saidpur Village has not become more livable after the renovation works. The development did not improve the life of the residents of the village and any income that has been generated by tourists goes to the posh restaurants managed by outsiders and a forced sense of history has been given to the area (Figure 34).

\section{CONCLUSIONS}

The cultural character of the heritage renovation of Saidpur Village is not of an authentic nature and has greatly affected the integrity, history and culture of the site. The culture of the village has been affected by the influx of tourists - both local and international, creating a visible and physical barrier between the locals and visitors. 


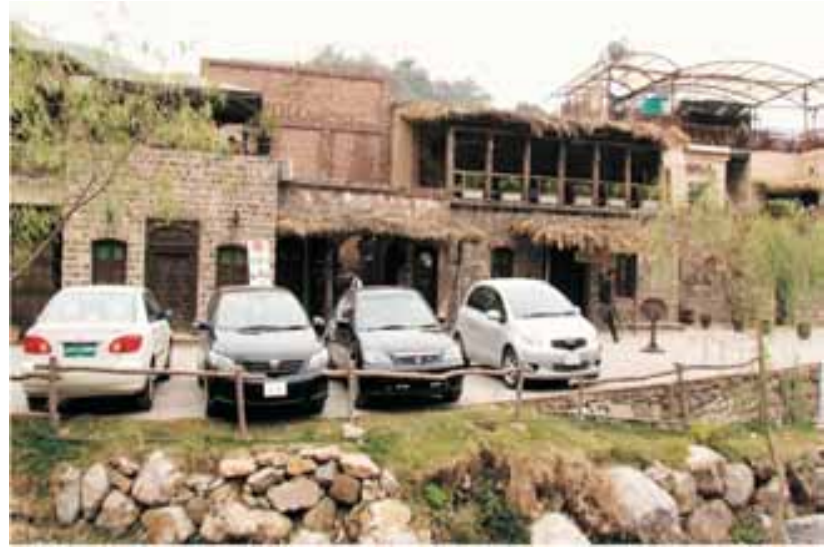

Figure-34: Fancy cars outside an exclusive restaurant

The new elements and buildings added to the village do not have the same cultural basis in terms of architectural styles, and lack relevance to the area or any historical connection to the 5illage. Very few of the carved doors, windows, treatment of wood carvings and colors chosen for the finishes were reminiscent of local and indigenous styles.

Similarly the use of mud plaster over the existing houses to give them an indigenous look was visually appealing, but care should have been exercised in giving a diversed look by employing brick, mud and stone as building materials, as some buildings made entirely of stone look out of place. Furthermore, the painting of various houses dotted around the village with an ochre-orange tone failed to produce an overall atmosphere of harmony, as the lanes and pathways were broken and depleted and only the buildings were attended to (Figure 35).

The overall visual environment within the village also changed because of removal of various houses, changing roof heights and by painting some façades. These interventions led to the removing of the visual clutter produced by indigenous housing, which was an inherent character of the area.

All the works done focus on the improvement of the tourist oriented central open area and the approach to Saidpur Village. An unintended outcome of the restoration has been social exclusion with the historic buildings turned into fashionable eateries that low income people cannot afford. The increased volume of tourists challenges the balance of the needs of tourism, culture and the normal life of the residents.

Some negative impacts of the renovations include eviction of local persons, non involvement of locals in the decision

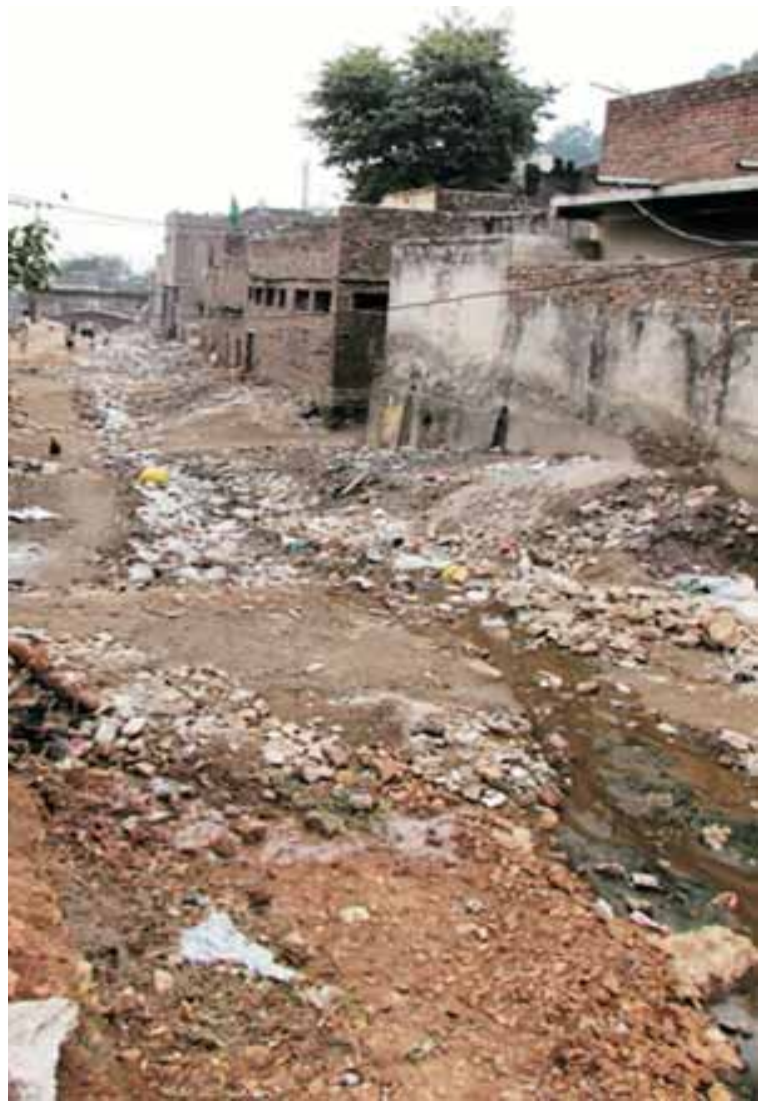

Figure-35: View of village street

making process, no improvement in sewage and sanitation lines of the village, no planning for removal of garbage produced by tourists, lack of local people's involvement in control over the environment, destruction of original architectural integrity of the historic buildings and import of unauthentic imagery and decoration and cultural 'erosion' of the traditional values of the area.

On the other hand there have been some benefits of the project which include adaptive re-use of the dharamshala, creation of a museum for the city of Islamabad, cleaning up of the village, some employment opportunities and income generation for the local craftsmen.

Conclusively, historic preservation programs are proven engines of economic growth that may help to attract investment into historic neighborhoods. These can then go towards improving the infrastructure and quality of lives of the residents as well as attract tourism revenues. Countries like Pakistan, that are rich in cultural and historical resources, should manage these resources more sustainably to make them economic assets for the locality and the city. 


\section{REFERENCES}

2005, Islamabad-Saidpur village heritage site, viewed 20 March 2010, from http://www.urbanpk.com.

2012, Saidpur, Islamabad, viewed 4 April 2011, from http://en.wikipedia.org/wiki/Saidpur,_Islamabad

2009, Standards for restoration and guidelines for restoring historic buildings, viewed 12 March 2009, from http://www.nps.gov/history/hps/tps/standguide/restore/restore_standards.html.

Admin, 2009, Islamabad: CDA to further beautify, expand Saidpur model village, viewed 22 December 2009, from http://www.opfblog.com/8683/islamabad-cda-to-further-beautify-expand-saidpur-model-village/.

Icomos, 1931, The Athens Charter for the restoration of historic monuments, viewed 22 March 2009, from http://www.icomos.org/athens_charter.html

Khan, S. and Imdad, A., 2010, Mapping of the architectural heritage of Islamabad, Unpublished report.

Jing, F., 2008, Best practices on social sustainability in historic districts, UN Habitat, UNESCO, Beijing.

Qalandar, M., 2008, A Trip to Saidpur: Khawaja Khizar in Islamabad, viewed 22 March 2009, from http://pakistaniat.com/category/mast-qalandar/

'CDA ignores locals' priorities', The Nation, June 12, 2008, viewed 4 April 2011, from http://nation.com.pk/pakistan-newsnewspaper-daily-english-online//Regional/12-Jun-2008/CDA-ignores-locals-priorities

UNEP, 1992, Rio declaration on environment and development, viewed 22 March 2008, from

https://en.wikipedia.org/wiki/Rio_Declaration_on_Environment_and_Development. 